\title{
BACTERIAL INDICATORS OF FAECAL POLLUTION OF WATER SUPPLIES AND PUBLIC HEALTH: A REVIEW
}

M.E. EJA

(Received 30 October 2001; Revision accepted 30 December 2001 )

\begin{abstract}
Bacterial indicators of faecal pollution of water supplies and their significance to public health are reviewed in this paper, to highlight their levels of general acceptability and suitability as safeguards against health hazards associated with water supplies. Regular bacteriological analysis with the sole aim of detecting faecal coliform as a confirmation of faecal pollution, is shown to constitute a safeguard against health hazards arising from the consumption of faecally-polluted water. It is also shown that available indicators cannot be fully relied upon for total safeguard espericially as Cryptosporidium oocysts and Giardia cysts have been implicated in some water-borne outbreaks of gastroenteritis. Furthermore, there are still problems of confusing ecology, characterization and taxonomy, growth temperature in both temperate and hot climates, coupled with the fact that several non-classical indicators, e.g., Bifidobacterium, Bacteroides, Eubacterium, etc., have been found to be equally attractive as apparently reliable indicators. This confusing situation appears to have created considerable doubt on the general acceptability of classical indicators (e.g., coliforms, Streptococcus faecalis and Clostridum perfringens), as safeguards against water-related infection. In perspective, further research on methods of detecting reliable indicators, in addition to maintaining hygienic principles in homes, are recommended.
\end{abstract}

KEY WORDS: Water Pollution, Bacterial indicators, General acceptability, Public Health.

\section{PNTROOUCTION}

The greatest danger associated with water supplies is contamination by human and animal faeces (Lynch and Poole, 1979). Human faeces. human urine and animal excreta are the principal vethicles for the transmission and spread of many water borne diseases (Cabelli, 1978, Pipes, 1978). For instance, gastroenteritis, dysentery, cholera, typhoid and paratyphoid fever, infective hepatitis and others are traceable to water polluted by human faeces (American Public Health Association, 1985). Water polluted by human urine may carry causative organisms of leptospirosis, lyphoid fever, schistosomiasis, eic., while water polluted by animal excreta is, to some extent, a source of salmonellosis. It has been noted that animals and birds, e.g., seagulls, may carry human intestinal organisms pathogenic to man (Reports on Public Health and Medical subjects, 1969, Benoit, et al., 1993).

Some of these infections are the chief causes of death, especially of infants, in societies where poverty, malnutrition and poor hygienic conditions prevail as in developing countries (Feachem et al., 1977). "Poor sanitation habit and improper waste disposal are responsible for the entry of sewage or excrement containing pathogens into water supplies. Notab!y, the problems of waste disposal began with the formation of agricultural communities based on smail permanent settlements (Lynch and Poole. 1979). The wastes produced by the communities were disposed by spreading on agricultural land to promote fertility of soil, or discharged into convenient watercourses. As these settlements grew into large villages and towns, waste disposal became a major problem. Suitable land for disposal of waste was limited, and so increasing use was made of the rivers and estuaries. Apparently, hygienic collection, transportation, treatment and disposal of human excreta (including the use of excreta in agriculture and biogas production) are extremely important for the health of a community (Fattal et al., 1981. Fattal, 1983, IRCWD Repori No. 05/85, 1985). Although excreta may be economically justified in agricultural use and biogas production, its use requires technologies that exclude unacceptable health risks.

Water has a very significant effect on human health. The relationship between water and health has been recognized from the time of Hippocrates, if not earlier, in the association of marshy places with fevers (Feachem. McGarry and Mara, 1977). Yet, until the second half of the $19^{\text {th }}$ Century, mankind had no true appreciation of the signifiçance of water as a vehicle of disease. In 1855, Snow was the first to show a precise relationship between a disease and water in his 


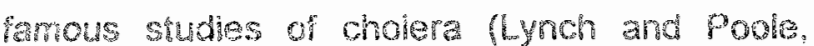
1979). He wes dosmiy follower by Budd (1873) Wha demopstrated the spread of tybhoid though woter supplies. The works of snow and Budd were crucial in developing the public awareness of the mponatice of controllimg water polution (t.znen and Poobs, 1979 ).

Cholera and typhoid which ane caused by the bacteris vibro choleras and samonela typh respewhely, were pendemic in Europe during the

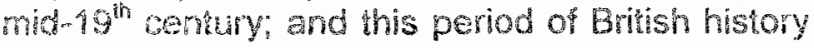
marked the beginning of great improvements in both the disposal of sewage and the provision of potable water (Wunch and Poole, 1979). These improvements or advances in the control water polution, are one of the greatest contributions aver made 10 she health and the quality of life of the human poputation.

Today the situation has changed very little in most third world countries. In Africa in Perticula: the problem is not that of space for waste disposet. is is one of ignorance of the healh impication of improper waste disposal, and the approphate rechnology ho handle waste and conthol Mater polution. The picure is not different he most Asian conmunises. Some improvements nave however beem made in thin Anerica.

it is satistying that mankind now kowns ond accopts that ratally poluted water why is definity the source of these infections under ciscussion, but measures already taken by man for the control of the infections are still rok adequate. For instamce, the detection of a tracer bacterium (ot hucator bacterum) sill has sone problems of general acceptability in terms of ecology. growth conditions in hoth temperate and hot cimates, specificity of manacteristics. taxomomy and absolute rellabiby as indicantor. This siudy aims to review these problems ard relate them to pubtic heath and control of water pelated infocions.

\section{WATERERELATED DISEASES}

lthes been chstomary lo classity water bome human pathogenic diseses according to the microbes causing the infections. Few sxamples ars salmonellosis caused by samonellae, shigellosis caused by shigella speries, giandiasis caused by Giardia species and schistosomiasis caused by Schistosoma species. This system of classification has not been useful in the consideration of how to improve water supplies. The mode of spread is important in the consideretion of improvement of water supplies. Thus, it has been more useful to reclassify infective diseases associated with water supplies into four calegories (White, Br.y and White,
1972, Bradley. 1977, Feachem, 1977). These categoriss.

1. Infertons spread through water supples (i.e. drinking water) are known as water bone diserases.

2. mifestons due to lack of werer for personal hygleme are known as Materwashed diseases.

3. Infections transmited through aquatic arimals ars know as water-based diseases.

4. Intections spread by waterdependent insects are known as diseases with water related insect vectors.

Diseases transmitted from infected persons tricugh water all belong to catsgory 1 . hance infected persons acquire the infections through oral contact with faecally contaminated water. Therefore, microbiologices cxamination besides chemical analysis of drinking wer, and the application of hygienic quality standards, are essential for the preservation of public headth.

\section{BACTERIOLOGICAL EXAMINATION OF WATER SUPPLY}

Because of the health danger associated with faecal contamination of water supplies, there is need for quality monitoring of the water in order to guard against health hazards arising from the consumption of such faecally. contamivated water.

Bacheriological analysis offers the most sensinive test for the detection of recent and theretore potentialy dangerous faecal pollution, which is the ratonale for the bacterological examimation of Mater. Smmotmes there could be defectwe treatment of water, and this could result in very serious heall hazards. Cross. connections with impure water sources, backsiphonage, leaks in mains and service reservoirs, access of materials via ball-cocks and stop valves, the effects of pressure variations or temperature and cessation of supply, are all possible means of raecal contamination of pipeborne water (Reports on Public Health and Medical subjerts, 1969, Holden, 19707.

In an exhaustive siudy of recrors like assirvilabie organic carbon (AOC) in water. disintectant residual and operational parameters ratated to coliform regrowh in drinking water. Lechevaller. of at. (1996) condurled that the occurrence of colifom bacteria within a distribution system was dependent upon a complex interaction of chemical, physical, operationat and engineering parameters, amd no single factor could account for all the colitom occurrences. 
Traditionally, the presence of coliforms in water supply indicates faecal pollution through cross connection, inadequate treatment, or inability to maintain a disinfectant residual in distributed water. However, indicator microorganisms have since been recognized in fully treated (finished) water supply; for instance, in 1930, the American Waterworks Association Committee on water supply reported on the problem of regrowth of Bacillus coli in drinking water systems (Committee on Water Supply, 1930). Adams and Kingsbury (1937) described the finished water at the point of entry into the distribution system as free of indicator bacteria. It is however evident that coliforms may be found in finished drinking water, and may not be related to faecal or pathogen contamination, or to waterborne disease (LeChevallier et al., 1996). The problem of regrowth of coliform bacteria has become of paramount importance with increasing stringent water quality standards. Infact, criteria by which a variance to the Total Coliform Rule could be granted, had been developed by the United States EPA (Federal Register, 1991).

Recent studies (Carmichael et al., 2001) further cast doubt on the use of classical indicator organisms as safeguard against faecal contamination of water supplies. For instance, in the examination of phytoplankton from the dialysis clinic water source, following human fatalities from cyanobacteria in Brazil, $19.5 \mu \mathrm{g} / \mathrm{l}$ of microcystin which was 19.5 times above World health Organization level for safe water supplies, was detected. In fact, Freeman (2001) reports that a Harward research tear. pollution, having observed that viruses were extremely abundant in marine waters where they often survived longer and more resistant to sewage treatment than bacteria, concluded that bacterial indicators are inadequate surrogates for overall pathogen levels. Rather, the Harward team proposed that surveillance methods that focused only on these indicators were no longer adequate to protect health. Thus the development of surveillance methods using polymerase chain reaction, fluorescent antibody, or monoclonal antibody techniques, in addition to monitoring algal populations, should be preferred (Freeman, 2001)

\section{RATIONALE FOR THE BACTERIOLOGICAL EXAMINATION OF PUBLIC WATER SUPPLIES}

The danger associated with faecal contamination of water supply is the possible presence of pathogens. One would have expected that bacteriological analysis of water would have involved principally the detection of pathogens in the water Unfortunately, the direct search for the presence of specific pathogenic bacteria or viruses in water is impracticable for routine control purposes (Reports on Public Health and Medical subjects, 1969). This is because pathogens present in water are usually greatly out-numbered by the normal intestinal organisms, and tend to die out more rapidly (Reports on Public Health and Medical subjects, 1969). Secondly, isolation of, and specific tests on all possible pathogens would require large volumes (several litres) of water, and generally involving complicated procedures besides biochemical and serological tests on pure cultures (Reports on Public Health and Medical subjects. 1969, Holden, 1970, American Public Heaith Association, 1985). The procedures are even more complicated and lengthy in the isolation of viruses.

Therefore, simple and rapid tests have been developed for the detection of normal intestinal bacteria that, "in this way, are used as indicator or tracer bacteria of faecal pollution of water, their presence indicating only that pathogens might also be present. Hence, if water is found to contain faecal indicator bacteria, it is considered unsafe for human consumption. This is the rationale for the bacteriological examination of public water supplies developed in Europe and the United States of America around the turn of the $19^{\text {th }}$ century, with the major aim of reducing the incidence of epidemics of water-borne diseases (Holden, 1970, Pipes, 1978, American Public Health Association, 1985).

THH."absence of indicator organisms does not guarantee a 'pure' sample of water because. no relationship has been claimed between the presence or absence of indicator microorganisms and polluting materials (Lynch and Poole, 1979). Townsend (1992) has observed that there is spatial variability in indicator/pathogen relationship. Some studies have shown that water may contain pathogenic bacteria without showing well marked corresponding presence of indicator organism. Escherichia coli. For example, during sporadic cases of enteritis caused by Salmonella montevideo in Galilee, Israel, examination of well waters (Seligmann and Reitler, 1965) revealed the presence of various salmonellas, including $S$. montevideo, accompanied in some cases by low or even zero $E$. coli counts. It was inferrea that the waters had become contaminated and that the salmonellae and $S$. montevideo in particular, had survived drying more effectively than $E$. coli (Seligmann and Reitler, 1965). Similarly, S. typhimurium epidemic in Riverside, California, was attributed to the water supply, and even though this organism was found throughout the 
distribution system, coliform counts were correspondingly lower than 2.2 percent per $100 \mathrm{ml}$ sample in most cases (Holden, 1970).

The principle of using indicator bacteria to assess bacterial quality of water is, still epidemiologically valid throughout the world, although with some restrictions when applied to waters and waste-waters in hot climates (White, Bradley and White, 1972). Secondly, recent studies using improved detection techniques for pathogens, have shovn that certain pathogens (e.g., Salmonella species, viruses) may survive longer in natural environments and also be more resistant to chlorination than the conventional faecal indicator bacteria. (White, Bradley and White, 1972, Freeman, 2001). Sen and Jacobs (1969) have demonstrated the survival of pathogenic vibrios and Salmonellae in at least 5 per cent of samples in chlorinated, unfiltered water from Hoogly River distributed in Calcutta. Therefore there should be caution in accepting the wholesomeness of water if analysis does not show indicator organisms. Moreover, absence of outbreaks of water-borne diseases when faecal indicators are used as a yardstick for hygienic quality, warrants continuous application of the use of indicator organisms to confirm faecal pollution.

\section{INDICATOR BACTERIA}

Indicator bacteria form a large group of obligate and facultative anacrobic bacteria, as well as small populations of aerobic bacteria. They constitute the normal microbial flora of the gut of man and other warm-blooded animals.

Indicator bacteria (or tracers) of faecal contamination ideally should fulfil some requirements (Reports on Public Health and Medical subjects, 1969, Pipes, 1978, Cabelli, 1978).

They must be:

a) normal members of the intestinal flora of healthy people;

b) exclusively intestinal in habitat, hence exclusively faecal in origin when found in the environment;

c) absent in non-human animals, although this condition is not yet met by any of the bacteria used at present;

d) present whenever faecal pathogens are present or might be expected to be present;

e) present in higher numbers than faecal pathogens;

f) unable to multiply outside the intestine, with a die-off rate slightly less than that of faecal pathogens;

g) resistant to natural antagonistic factors in water and waste water treatment processes, to a degree than faecal pathogens;

equal to or greater

h) easy to detect and count and detectable in low densities, and

i) non-pathogenic.

No one bacterial species or group at present in use completely fulfills all these requirements, but a few come close to doing so. In conventional water bacteriology, three main groups or species of bacteria are used as faecal indicators. - They are rightly described as "classical" indicators (Opara, 1978). they are:

1. coliform bacteria made up of total coliform (faecal coliform and non-faecal coliform).

2. Faecal streptococci

3. Clostridium perfringens (C. welchii)

A number of bacteria described as nonclassical (Opara, 1978) have been proposed to be used for the same purpose (Feachem,1977, Cabelli, 1978). They are: Bifidobacterium species, Pseudomonas. aeruginosa, Bacteroides, Pepto(strepto)coccus and Eubacterium species, all of which are relatively abundant in human faeces (Feachem, 1977). Diet and ethnic factors can influence the bacterial flora of the human intestine (Feachem, 1977). In a study of the microflora of the faeces of different human populations (Drasar, 1974), an insight into the effect of diet and socio-economic changes on the intestinal flora has been given. How the effect comes about has not been convincingly explained. In any case, Drasar (1974) observed that, for most groups of organisms, the distribution pattern was remarkably similar in about six groups, and that anaerobic organisms (Bacteroides, Bifidobacterium, Eubacterium and Clostridium) greatly outnumbered the facultative bacteria, and the greatest geographical variation in numbers was in Enterococcus group.

However, in a recent study to determine, among others, the effect which changes in diet would have on the shedding of E. coli $0157: \mathrm{H} 7$ by sheep, besides the effect of changing of location (confinement to pasture), Kudva, et al.' (1995) observed that the diet change presumably induced selective microbial growth in the intestine of the sheep so that the level of $E$. coli $0157: H 7$ shed became detectable, or the diet change might have increased animal susceptibility to colonization with E.coli $0157: \mathrm{H7}$, so that horizontal transmission was increased even though the animal was no longer penned. Kudva, et al. (1995) therefore hypothesized that diets high in nutrients and low in fibre induce a lower incidence of transmission and/or shedding of fewer E.coli 015:H7 cells, but do not induce clearance of the organism from the intestine. They further stated that conversely the diets low in nutrients and high in fibre and briefly 
withinolding feed, can both induce shedding of larger numbers of $E$. coli 0157:H7, and/or increase subsceptibility to new intestinal colonization, besides inducing elimination of the organism. The mechanism of these dietary effects is assumed to result from changes in volatile fatty acid (VFA) concentrations, in which case, diets with increased fibre content and withholding feed are both known to decrease the VFA concentrations in the ruminant gut and affect bacterial colonization pattern (Brownlie and Grau, 1967, Grau et al., 1969, Wallace et al., 1989).

The hypothesis of Kudva, et al. (1995) could partially explain the differences in "the bacterial flora of the intestine of different human populations. This is of significance to public health. It could be inferred that dietary habit which is influenced by cultural or ethnic disposition can affect the rate of transmission and shedding of $E$. coli, and thus the rate of faecal pollution of water supplies.

\section{CLASSICAL INDICATOR BACTERIA}

\section{Coliform Bacteria}

Coliform bacteria are present in human and animal faeces. The number could be up to $10^{6}-10^{9} / \mathrm{g}$ of human faeces (Holden, 1970). Irrespective of doubts cast from time to time on the validity of faecal coliform, $E$. coli, as an indicator of faecal contamination of water supply (Dutka, 1973, Evison and James, 1974), the opinion that $E$. coli, adequately defined, is the most sensitive and reliable indicator of excretal pollution at our disposal has remained unshaken till recently (Holden, 1970, White, Bradley and White, 1972, Feachem, 1977). It's sensitivity makes it possible to detect at least one cell in $100 \mathrm{ml}$ of water (EPA- 600/8-78-017, 1978).

Two main groups of coliform are known. They are faecal and non-faecal coliform (together forming total coliforms). The former are exclusively faecal in origin. The latter can often be found in faeces, but are also naturally occurring in faegally unpolluted waters and soils and even vegetable matter (Reports on Public Health and Medical subjects, 1969). . Hence the presence of the latter is regarded as presumptive evidence of faecal pollution of water supply, and should as well as faecal coliforms be absent from treated water supplies (Reports on Public Health and Medical subjects, 1969). In the bacteriology of surface water and wastewater, they are of much less importance. This is because, under suitable conditions, e.g. in the presence of decaying vegetation in natural waters, and on pump packages, cellulosic pipe-jointing material, leather tap washers, jute yarns used in pipe joints, and gatural orqanic material in water distribution system, especially in hot climates, multiplication of non-faecal coloforms can take place (Reports on Public Health and Medical subjects, 1969, Deaner and Kerri,1969, Dutka, 1973. Holden, 1970, Evison and James, 1974, Opara, 1978). In this regard, the occurrerse is not necessarily related to faecal pollution or to the degree of the latter. Several studies cited by Opara (1978) have created some doubts 0,1 the reliability of the use of $E$. coli as an indicator of faecal pollution. These doubts have arisen from the fact that the normal flora of human faeces in India, Ceylon, Egypt and Singapore have been shown to contain aerogenes (cloacae group) and Citrobacter which have proved positive to Eijkman test at $44^{\circ} \mathrm{C}$, a test which characterizes $E$. coli (Reports on Public Health and Medical subjects 1969).

As defined in Reports on Public Health and Medical subjects, (1969), the coliform organisms are "gram-negative, oxidase-negative, non-sporing rods capable of growing aerobically on an agar medium containing bile salts, and able to ferment lactose within 48 hours at $37^{\circ} \mathrm{C}$ with the production of both acid and gas". Some coliforms are widely spread in certain forms of vegetation. They ferment lactose at $30^{\circ} \mathrm{C}$ and are not of epidemiological importance.

E. coli" are also coliforms as defined above, but are differentiated from others by their ability to ferment lactose with the production of acid and gas at both $37^{\circ} \mathrm{C}$ and $44^{\circ} \mathrm{C}$ in less than 48 hours; and can also produce indole in peptone containing tryptophan (Reports on Public Heatth and Medical subjects, 1969, American Public Health Association, 1985). They cannot produce acetyl methyl carbinol and are methyl-red positive (Carpenter et al., 1966, Reports on Public Health and Medical subjects, 1969, Cowan and Steel, 1974, American Public Health Association, 1985).

\section{Faecal streptococci}

Faecal streptococci are gram-positive cocci which have the ability to grow at $45^{\circ} \mathrm{C}$ in the presence of 40 per cent bile, and in concentration of sodium azide which are inhibitory to coliform organisms and most other gram-negative bacteria (American Public Health Association, 1985). Some species resist heating at $60^{\circ} \mathrm{C}$ for 30 minutes, and will grow at $\mathrm{pH}$ 9.6. and in media containing 6.5 per cent sodium chloride (Reports on Public Health and Medical subjects, 1969). They are present in human and animal faeces with numbers ranging from $10^{5}$ to $10^{8} / \mathrm{g}$ (Holden, 1970). They are thus smaller in number than total coliform, although the ratio of total coliform to fecal coliform may vary considerably between different communities (Feachem. 1977). 
Faecal streptococci comprise Lancefield's serological group D (Cruickshank et al., 1975), mainly the Enterococcus groups ( $S$. faecalis, $S$. faecium, S. durans) plus $S$. bovis and $S$. equinus which may also be found in water (Holden, 1970). Other streptococci, S. mitis and S. salivarius, although not in the Lancefield's serological group $D$, can occasionally be present in the mouth. They originate from the mouth and are swallowed in the saliva (Reports on Public Health and Medical subjects, 1969).

As stated in Standard Methods for the Examination of Water and Wastewater (American Public Health Association, 1985), the main value of faecal streptococci lies in assessing the significance of doubtful results from the colftorm tests, especially when larger numbers of coliforms occur without the presence of $E$. coli. Detection of faecal streptococci serves to confirm the faecal origin of pollution. Hence faecal streptococci tests are mostly used as supplementary to coliform tests, and are especially of value in natural waters and samples from repaired mains. The greater resistance of faecal streptococci to marginal chlorination than the coliform bacteria, also increases the value of the former for use for the same purposes (American Public Health Association, 1985). Two subspecies of serological group D streptococci have been identified (Cruickshank et al., 1975). They are atypical S. faecalis (var. zymogenes) which hydrolyse starch, and $S$. faecalis (var. liquefaciens) which occur in faecally polluted as well as unpolluted environments. These strains are essentially non-faecal in origin, and in routine tests, are not distinguishable from truly faecal streptococci. The predominance of one of these subspecies (or biotypes) at lower densities of faecal streptococci, would render the usefulness of faecal streptococci indicators questionable, especially in drinking water microbiology.

\section{Clostridium perfringens (C. welchii)}

This is a gram-positive anaerobic sporeforming rod, exclusively faecal in origin. It can also be pathogonic (but not enteropathogenic) causing gas gangrene and food poisoning. The number in human and animal faeces could range from $10-10^{7} / \mathrm{g}$. It can persist for a long time outside the intestine and can resist chlorination because of its possession of endospores (Reports on Public Health and Medical subjects, 1969). It's value lies, therefore, in demonstrating remote or intermittent pollution, or confirming the faecal nature of contamination when only coliform organisms other than E. coli are piesent (American Public Health Association, 1985, Reports on Public Health and Medical subjects, 1969) In wastewater bacteriology, persistence for a long time outside the intestine is a disadvantage because of the formation of residual domant populations, which might not reflect the degree of possible pathogenic contamination. Hence the test is mostly used for the same purpose and additionally to faecal streptococcus test.

\section{Non-classical indicator bacteria}

The non-classical indicators are Bifidobacterium species, Pseudomonas aeruginosa, Bacteroides and Eubacterium species.

Bifidobacterium species are gram-positive rods with a tendency to forming rudimentary branches. They are non-sporing, non-acidfast, anaerobic, catalase-negative, and can ferment sugars. In fact, the species are characterized by their crude Y-shape (Cheesbrough, 1984). The best known is Bifidgbacterium bifidum which is easiest to identify because it has the ability to attack sugars (Reuter, 1971). From ecological point of view, studies on the distribution of these organisms have shown that they are found in the faeces of infants and adults, in human vagina, and in the faeces (or rumen contents) of animals and birds (Reuter, 1971). Zani et al. (1974) has demonstrated the presence of Bifidobacteria in the faeces of piglets.

In human faeces Bifidobacteria are present in large numbers, $10^{8}-10^{11} / \mathrm{g}$; the number may differ among people of different socio-economic groups, races and diets, as already highlighted in this paper. About eleven main species isolated from human faeces have been recorded (Buchanan and Gibbons, 1974). The most common species are $B$. adolescentis, $B$. infantis, in addition to B. bifidum, Lactobacillus bifidus, and $B$. brevey which are found in animal sources (Opara, 1978). They have been recently proposed for use as faecal indicators in tropical waters, as they overcome the principal disadvantage of faecal coliform counts in tropical samples, especially as a significant proportion of coliform strains which are not of faecal origin, can ferment lactose and produce indole at $44^{\circ} \mathrm{C}$ (Evison and James, 1973, 1974).

Pseudomonas aeruginosa is a gram. negative, actively motile, non-sporing, strictly aerobic bacillus. It is very widely distributed in nature. It is a known pathogen for man and animals, and because it is primarily associated with human (unlike animal) faeces, and has better survival characteristics than coliforms, it has been suspected as a possible indicator of faecal pollution (Ringen and Drake, 1952).

Pseudomonas aeruginosa has a doubtful status as an intestinat indicator organism because of poor reliability and multiplication in surface 
Waters; thus it has rather been recommended as a sensive indicator of swimming pool hygiene, as is often incriminated in eye and ear

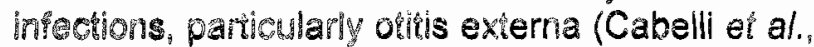
1978. Gabli, 1978, American Public health Association, 1985).

Barbroives species fopecially $B$. frolitis), Poptococous and peptostreptococcus species and Eubactorium species, are also nonspoptrating anatrobes, nomally occurring in faces. They have been proposed as faecal indirators, although there is no sufficient impomaton avaliable as 10 their usefulness (Evison and James, 1973,1974 , Feachem, 197\%, Opgras. 1978). Opara (1978) has obsened that $B$. haghis and Bifidobacista have the potential for being valuable indicators of paecal pollution in the ropics.

\section{parspertives}

From public health poins of view, there is rese to monitor water quality in opder to guard againgl hoalth hazards arising from the consumption of faccally - polluted water. Bacteriological whatysis of water offers the most deilicate rest fop the detection of faecal pollution; and in principle, the detection of faecal coliform conifirms faecal pollution. The safeguard is that, where there is faecal coliform in water, there is a probakilivy that anteris pathogenic bacteria could bos present.

However, it is now well established that colliorm bacteria are haterogeneous group of baererial species made up of Escherichia, Klobsialla, Citrobabter, Enterobacter and Aeromonas genera (Menon, 2001). Excluding Escherichia coli which is exelusively faecal in origin, the other four gensera are widely distributed in naturs and commonly found in soils, on vagetation and in industrial waste; further, the nonofiacal coliom biotypes are frequently associatod with surface runoff and have the sendency to mulviply in rutritionally rich waters (Repons on Public Health and Medical subjects, 1969. Menon, 2001). Menon (2001) has proposed that there should be more investigation as to the origin of the coliform organisms. because the presence of total coliforms in surface waters does not always imply faecal contamination, whil the sanitary significance of these bacteria becomes doubtful if no obvious pollution sourcs is found.

In fact, the use of indicator bacteria as a sof ${ }^{2}$ guard in watep treatme.it plants has been proved not to be $100 \%$ safe following the waterborne outbreaks of gastroenteritis in the U.K. in which Crgptosporidium and ciardia have been implicated and traced to wat plants which met all current statutory microbiological and chemical standarsts (Amon; 1990).

Because Cryptosporintum ogeyses and Giardia cysts are commonly found in surfacs waters contaminated by catte and sheep taeces, water treatment process could be challenged by large number of these parrsites in water distribution system (Byme, 2002). Cryptosporidum oocyst and Giardits cysts.can survive in water for several months urvilis the indicators, and are highy rasigiont to chlorination which has no effect at all to particularly cryptosporidum (Korien of al. 1990. Adam. 1991). This implies that the stablished bacterial indicators for water quality. for example the coliform group, are not appropisate for these Cryptospordium and Giardia (Byme. 2002).

Up ill now, jaecal coliform is acchismed the most reliable indicator of paceal pollution of water. Yet there are still problems of general acceptabiity in terms of ecology growth conditions in both temperate and hot whinates. specificity of characteristics, taxonomy and absolute reliability as indicator, eic. Foringtance, El-Ghodd ot al. (1998) observed that the highly dominant baxons for some water samplas were Alcaligenes sp. End Enterobocter sp. although most dominant takons were Xanthobacter sp. and Pseudomonas sp.

It appesis that the ecology of colitom is not conclusively understood and this poses a problem in epidemiological inwestigation. For instance, Paecal coliform is known bo orcur in the intestine of birds and animals other than man (Reports on Public Health and Medical subjects. 1969). A recent investigation of the input of faecal matter to stornwater dpains in Rippleside area of Geelong. Victoria with the combined use of sterol biomarker and four subgroups of bacterial indicators, Leeming at ab. (1998) indicated that the combination approach could greatly assist in olstinguighing sources of paecal pollution, but the use of either gterol or other single indicators alone was inadequate 10 fully discern faecal contamination from human source. Therefore, there is a limitation to the value of demonstrating $E$. coll (faccal coliform) in water supplies, as the source of the excrement, namely. whether from man. beast or bird, cannot be distinguished since the same organism can sceur in all. This situation makes the investigation of the ecology of coliform inconclusive.

Burman (1961) has used difrerences in growh temperatures to differentiate intestinal coliforms from those isolated from natural environment. He observed that intestinal coliforms have an optimum growth temperature near $37^{\circ} \mathrm{C}$ whereas those isolated from sources more remote from faecal polution more prequently 
have an optimum growth temperature near $30^{\circ} \mathrm{C}$. Doubt further arises from the use of optimum growth temperature to differentiate coliforms from natural habitats from those of intestinal origin in. rropical climate as the natural temperature in hot climate may be even higher than $30^{\circ} \mathrm{C}$ or $37^{\circ} \mathrm{C}$. Regulated temperature in the laboratory has the denger of providing a result not obtainable under natural conditions.

From taxonomic point of view. bacererologists have previously carried out a cifferential test of coliforms by IMVic (Indole, Methyl-red, Voges-Proskauer and Citrate wilization) test (Edwards and Ewing, 1962). It has been noved that in using differential test, not all strains taxonomically assigned to coliform group necessarily conform to the coliform definition used earlier in this paper (Reports on Publis Health and Medical subjects, 1969), because (i) not all strains ferment lactose, and may not produce gas if at all they do; (ii) not all lactosefermenting or sheen producing gramnegative rods found in water are coliforms (they may be Aeromonas); (iii) not all strains of a given species will react uniformly in a given substrate; (iv) the traditional "IMVic" tesis which are useful for coliform differentiation do not provide for complete identification, and inerefore require additional biochernical test; (v) indicator organisms of the family Enterobacteriaceae are known to ferment lactose with the formation of gas within $48^{\circ} \mathrm{C}$ at the appropriate temperature, on an Endo-type medium containing lactose, but aerogenic (non-gas-producing) lactosefermenting strains of $E$. coli may also be encountered (American Public Health Association, 1985)

Thus by using other tests for differentiating organis of the family Enterobacteriaceae, many of the so-called colform organisms isolated from water may be seen do differ from those isolated from the intestive or from clinical materials, and may therefore be difficull to assign to the recognised gevery of the coliform group. The significance of the coliform organisms other than $E$ coli found in water might therefore generate considerable doubt, although with increase in knowledge of methods of differentiation, it may become possible to accurately distinguish those of intestinat origin from those of non-intestinal origin.

of interest 10 water bacteriologists is the fact hat some variants of Enterobacter aerogenes and cloacae also ferment lactose at $44^{\circ} \mathrm{C}$ with the production of gas (Holden, 1970). This has created doubi on the reliability of the use of $E$ coli as an indicator of faecal pollution. further doubls have been created by the fact that. the normal flora of human faeces in India.
Ceylon, Egypt and Singapore have been shown to contain aerogenes (cloacae group) and Citrobacter which have proved positive to Eij.'sman test at $44^{\circ} \mathrm{C}$ (Opara, 1978), a test which characterizes $E$. coli (Reports on Public Health and Medical subjects, 1969).

Looking at the requirements which indicators must fulfill, as has earlier been noted in this paper, no bacterial species or group in use, completely fulfills all the requirements, at present. Therefore the search for a reliable indictor is for now inconclusive.

\section{CONCLUSION}

The use of indicator organisms still remains epidemiologically valid in water bacteriology, but still requires further research to eliminate doubts and establish greater reliability. To a very large extent, however, regular bacteriological examination of water can contribute to safeguarding a population against epidemic outbreaks of water-related diseases. Of primary importance in the elimination of diseases are health education campaigns, teaching the application of basic hygienic principles in daily life, e.g., washing of hands after toilet, ensuring that no privies are sited over rivers whose water is used as drinking water by people downstream, etc.

\section{REFERENCE}

Adam, D. A. 1991. The Biology of Giardia spp. Microbiological Reviews. 55:706 - 732.

Adans, G. O. and Kingsbury, F. H., 1937. Experiences with chlorinated new water mains. J. N. Engl. Water works Assoc. 51:60-68

American Public Health Association., 1985. Standurd Methods for the Examination of water and waste water. IGth Ed. APHA. Washington.

Amnon., 1990. Cryprosporidium in waller supplies. Repont of llse group of experts; Chairperson, Sir Joln Badenoch. Department of the Environment. Department of Health. HMSO, London

Benoit, L., Broussenu, P., Sinard, P., Dewailly, E., Meiseis. M. Ramsay, D. and Jolly, J., 1993. Impace of the ring-billed gull (Larus delaworensis) on micribiological quality of recreational water. Appl. Environ. Microbiol. 59(4): 1228-30.

Bradley, D. 1. 1977. Healtr Aspect of Water Supplies in Tropical conntries. hi: Water. Wastes and Health in hot climates. Eds. R. Feachem. M. MeGiary and D. Mara. Jom Wiley and Sons, London. 
Brossulic, L. E. and Gewe, F.H., 1967. Effect of food intake on growth and survival of Samoneila and Escherichia coli in lize bovine rmmen. In gen. Microbiol. $46: 125.134$.

Buchanan, R. E. and Gibbons, H. E. (eds.). 1974. Bergey's Manual of Detcminative Bacteriology, $8^{\text {th }}$ edition. The Withan and Wilkins Co., Boltimore.

Budd. W. 1873. Typhoid fever: Is nature, mode of spreading and prevening Longmans green. London.

Burman, N. 1961. Mn: Water Treatument and Examination. Ed. W. S. Holden, 1970. A7J. Cinurchill London. Pp. 206-222).

Byme, M., 2002. The Derchion of Cryptospordium spp. Cocysts and Giardia spp. Cysts in water. City Amalysts Lid. Biotechology Centre, UCD. Oublin 4.

Cabelti. V.J. hentedy, H. and Levin, M.A., 1976. Pscudomonas aeruginosa -.. faccal colliom relationsloips in estuarine and fresh recreational watcers . Jour. W. P. F. 48 (2): $364-376$

Cabelli, V. A. 1978. Now Siandards for Enteric Bacteria In: Water Pollution Microbiology. Ed. R.Mitclucll. Wiley Interscisnce, New York.

Canthichael, W. W. Azevedo, S.M.1.O, An, Ji Si, Mohra, R.J.R., Jochimsen, E.M., Lau. S., Rinehart, K. L.. Shaw, G.R. and Eaglesham, G. K., 200!. Human Fatalities from Cyanobacieria: Chemical and Bacteriological Evidence for Cyanotoxins. Envirommental Health Perspecives, 109(7):663 608.

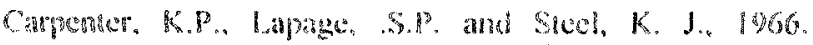

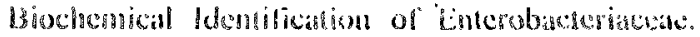
In: Identifgation methods for Microbiologists. Eds. B.M. Gibbs and Shimer. F.A. Academic press, Lempdon.

Cheestrongh M. 1984. Medical Laboratory Marun for Tropical Countrios. Vol.2, Microbiology. Tropical Healn Tuenology. Cambridge. England.

Commintes ow Water Supply. 1930. Bacterish allerybrowth ian distribution sysicms. Am j. Public Houlth. $20: 4850491$

Cowan. S.T. and sted. K. J. 197\%. Cowan and Sted munual for the identifieation of Medical bacteria. Cambridge University press. Pp. 103-11\%.

Cruickshank, R., Duguid, J.P., Marmion, B.8. and Swain, R.H., 1975. Medica Mictobiology. Vol. 2. $12^{\text {th }}$ Ed. The English Language Book Sociefy and Charchill hivingstone, Britain.
Deaner, D.G. and Kerri, K. D., 1969. Regrowth of Fatecal coliforms. Joumal of American Waterworks Association. 61: 465-468.

Drasar, B. S.1974. Some factors associated with geographical variations in the intestimal Microfortit. In: The Nomal Microbial flota of Man. Bils l.A. Skinner and I.G Carr. Academic press, Lombon. P'p.187-190

Datka, B.J., 1973. Coliloms are an inadequate index of water quality. Joumal of Environmental heahts. $36: 39-46$.

Edwards, P. R. and Ewing, W.H., 1962. Identification of Enterobacteriaccae. $2^{\text {mil }}$ Ed. Mineapolis, Burmess publ. Co.

El-Ghoddi, A.N., Marialigeti, K. and Nemedi, L., 1988. Baclerial Indicators of Pollution in Dandbo water and Sedimen. CEIOEM. 4(2): $161-169$

EPA- 600/8-78-01..1978. Microbiological Methods lot Monitoring the Environment: Water and Wastes. Washington, D.C.

Evison. W.Jl., and James, $A .1973 . \wedge$ comparison w the distribution of Intestinal Bacteria in Britain and East Alrican waters. 1. Appl. Bacteriology, 36:10\%. 118.

Evison, L.M. and James, A., 1974. Bilidebacterimi ass an indicator of Faecal pollution in water. Procedinge, $7^{\text {th }}$ Int Conl. on Water Pollution Research. Paris Pergamon press.

Fatal, B., 1983. The prevalence of viral heparis and ofluey species ol enteric discast in communities thilientus waster water in agriculture. Watcr Science Teclunology. 15:43-58.

Patual, B., Shumal, H.I., Wax, Y. and Davies, A.N., 1981. Sudy of enure disease transmission associnted with vastewater thilization in engriculumed commonities in Isract. In: Procecding of the water reuse symposium II, volume 3. Denver, Americam Waterworks Association, pp 2200.2215.

Fachem, R.G., 1977. Water Supplies for hov-income communifies: Resource allocation, Plonning and design for a crisis sifuation. In: Water. Wastes and Health in Hot cimates. Eds. R. Feachem. $M$. Megary and D.Mara. Sohn Wiby and soms. London.

Foachen, R. Megary, M. and Malra. D. 1977. War:, Wastes and Healh in Hot Climates. Jobu witey and sons, London.

Federal Register., 1991. Drinking water: National prinumy drinding water regulations; total coliforms. Fed Regist, 56:1556-1557. 
Freman, K.. 2001. Science Selections: Marine Pollution Makes Swimmers Sick. Euvironmental Health Perspectives. 109(7): $649-650$.

Cinu. F.ll., Browntie, L. and Smith. M.G., 1969. Erfects of food on numbers of Sahmonella and Escherichia coli in rumen and laeces of sheep. J. Appl. Bacteriol. 32:112-117.

Holden, W.S. (ed.)., 1970. Waler Treatment and Exammation. J. \& A. Churchill. London, 513 pp.

RrCWD Repert No. 05/85. 1285. Health Aspect of Nightsoil and Sludge use in Agriculture and Aquaculture, pat: $111 . \quad \wedge n$ Epoemiological perspective. l'repared by Deborah Blum and Richard $\mathrm{G}$. Fachem. Intcriational Reference Conto Waste Disposal (IRCWD), Switzerland.

Korich, D. G. Mend, s. Madore, M.S., Sinclair, M. A. and Sonhing C.R. 1900. Effects of Ozone, chlorine disi is, chlorise and monechloramine on Cryplosporitim partum oocys viability. Applied and Environas dal Microbiology. 57: 2610-2616.

Rudva, I. T., Halliekd I3. ans hovde, C.J., 1995. Ellect of diet on the shodum on Escherichia coil 0157:H7 in a sheep Model Applicd and Environmental Microbiology. 61(4): 1363-1370.

Lechevallier, M. W., Welch, N.J. and Smith, D.B., 1996. Full-scale studies of fictors related to coliform regrowth in driking water. Applied and Envirommentalmiciobiology. 62(7): 2201-2211.

Leeming, R., Bate, N., llewlet, R. and Nichols, P. D., 1998. Water Science and Techmology. IWA Publishing Vol.38, pp. 15-22

ynch, J.M. and Poole, N.J.. 1979. Microbial Ecology: A conceptual Approach. Blackwell Scientific Publication, London.

Mewon, A. S., 200: Shentish Safety. Kingzet Professional Strices Lot Candia.
Opara. A.A., 1978. The role of anaerobic farecal bacteria ats indicators of water pollution in hot climates. Ph.D thesis, University of [oundee (unpublished).

Pipes. W.O.(ed)., 1978. Water Quality and Health significance of Bacterial indicators of pollution. Workshop proceedings, Drexel University. Philadelphiat.

Reports on Public Health and Medical subjects., 1969. The Bacteriological Examination of Water Supplies. U.K. Reports No. 71. Ler Majesty's Stationery Ofrice, London.

Reuter, G., 1971. Designation of type strains for Bifido bacterium species Int. J. Syst.Bact.21:273:"

Ringen, L.N: and Drake, C.H., 1952. A study of the incidence of $P$ seudomonas aeruginosa from various natural sources.J.Bact. 64: 841-845.

Seligmanm, R. and Reiller, R., 1965. Fnertopallogens in water with low Escherichia coli litres. J. Amer. Waterworks Ass; $57: 1672$.

Snow, J., 1855. On the mode of communication of cholera hi: Microbial Ecology: A conceptual approach. 3.M. Lynch and N.J Poole (eds), 1979. Blackwell Scientilic publications, London. Pp. $226-245$.

Townsend, S. A., 1992. The relationships between salmoncilas and faccal indicator concentrations ir two pools in Australian wet/dry tropics. J. Appi. Bacteriol. 73(2): $182-188$.

Wallace, R. J., Falconer, M. I., and Bhargava, P.K., 1989. Toxicity "of volatile falty acids at rumen pil prevents enrichment of Esherichia coli by sorbitol in rumen concons. Curr. Microbiol. 19:277-281.

White, G. I., Bralley, D. J. and White, A. U., 1072 . Drawers of Water: Dontestic Water Use in East Arica. Chicnge University Press.

Zani, C, Biavai, B., Crociani, F. and Matteuzzi, D., 1974. Brfidotacteria from the laeces of piglets. J. Appl. Buct.37 $5.37-547$. 